九州大学学術情報リポジトリ

Kyushu University Institutional Repository

\title{
The Role of Forest in People's Livelihood: A Case Study in North-eastern Vietnam
}

Quang, Nguyen Vinh

Department of Forest and Forest Products Sciences, Faculty of Agriculture, Kyushu University

Sato, Noriko

Faculty of Agriculture, Kyushu University

https://doi.org/10.5109/10113

出版情報：九州大学大学院農学研究院紀要. 53 (1)，pp.357-362，2008-02-28. Faculty of Agriculture, Kyushu University

バージョン：

権利関係 : 


\title{
The Role of Forest in People's Livelihood: A Case Study in North-eastern Vietnam
}

\author{
Nguyen Vinh QUANG ${ }^{1 *}$ and Noriko SATO ${ }^{2}$ \\ Laboratory of Forest Policy, Division of Forest Environment and Management Sciences, \\ Department of Forest and Forest Products Sciences, Faculty of Agriculture, \\ Kyushu University, Fukuoka 812-8581, Japan \\ (Received November 9, 2007 and accepted November 30, 2007)
}

\begin{abstract}
This paper was formed to determine contribution of forest to income of different economic-conditioned households, as a way to see how important forest has still played in a forest-related community, after implementation of the new forest allocation policy in Vietnam. It was formed based on personal questionnaire-interviewed data of a Dao-ethnic community in north-eastern mountain region of Vietnam, where the policy has been implemented since 2000. The interview was conducted in April 2007 to all 41 households in the community. These households were then divided into three groups based on their per capita annual income, for purpose of comparison.

The paper showed that despite the policy that limited local people from overuse of forestland for cropping, all households in the study community still used large proportion of forest to cultivate subsistence and cash-income crops. Four-fifths of production forest land allocated to the community's households was used for swidden practices and cultivation of cinnamon (Cinnamomum cassia). Protection forest was also used to plant another cash income crop of cardamom (Elettaria cardamomum).

Overall, forest contributed large part in total income of the community's households, regardless they are better-off or poor. Income from cinnamon was especially important to the living of most of the households. However, forest-derived income of the richer households was considerably higher than that of the poorer ones. Data indicated that $83 \%$ in total annual income of the better-off households, $76 \%$ of the moderate, and $70 \%$ of the low income or poor households, were from forest. Since cinnamon is forest tree species that is beneficial for local people as well as good for the improvement of forest quality, the paper suggests expand cinnamon cultivation to other similar-conditioned places.
\end{abstract}

\section{INTRODUCTION}

Forest-covered areas in Vietnam occupy nearly 13 million hectares or $39.7 \%$ of the country's total land area (FAO 2005:191; Sam et al., 2007:142). Most of these forests are found in the upland regions and are the habitats of some 25 million people who belong to 50 of the country's 54 ethnic groups (Quang, 2003). These people are mainly poor minorities and have few other livelihood opportunities, rather than from forest (Swinkels and Turk, 2006; VFU, 2006). To these people, forest has been an important source for food, shelter, and other needs (Vien et al., 2005).

Yet owing to alarming degradation and reduction of forest quality and forest cover (Cari, 2005) caused, among others, by shifting or swidden cultivation and overexploitation of forests (Yamane, 2003:6; Sunderlin and Ba 2005; Sam et al., 2007:143), in the early 1990s the Vietnamese government has promulgated a new policy to allocate national-owned forestland to local organizations, groups of people, or individual households (Decree 02/CP 1994). The new policy's goals are to encourage recipients to protect their allocated forests and to replant trees in barren forestland (Sunderlin and $\mathrm{Ba}, 2005)$. Supporting programs to reach the goals have

\footnotetext{
Laboratory of Forest Policy, Division of Forest Environment and Management Sciences, Department of Forest and Forest Products Sciences, Faculty of Agriculture, Kyushu University

2 Faculty of Agriculture, Kyushu University

* Corresponding author (E-mail: nvquang@ffp.kyushu-u.ac.jp)
}

also been implemented in forest-received communities accordingly (Decision 661/QD-TTg, 1998; Swinkels and Turk, 2006).

However, since the forest-related people who are mainly ethnic minorities, poor, and very much dependent on forest for their living (Swinkels and Turk, 2006), are there any changes in livelihoods of those people under the policy? Or any differences in terms of economic activity between better-off and poor households after the implementation of the policy? This paper was designed to answer the questions, by determining the contribution of forest to income of different economicconditioned households. This is one of the ways to see how important the forest has still played in forest-related communities, under the new forest allocation policy.

\section{MATERIALS AND METHOD}

The study was conducted in April 2007 in a community named Bang Ha village in Dai Son commune, Van Yen district, Yen Bai province. It is located in northeastern mountain region of Vietnam and some 250 kilometers $(\mathrm{km})$ far from Hanoi. This community was chosen for the study because (i) it is located close to forest area in a mountainous region, where majority of its territory is classified forest land; (ii) its inhabitants have long history of use of forestland and forest resources (timber and non-timber forest products) for their living; and (iii) the new forest policy allocating forestland to its individual households has already been implemented in since 2000. Analyses of this paper were mainly based on pri- 
mary data derived from questionnaire interview to all 41 households existed in the community.

Two main data sets were used for analyzing role of forest in the living of Bang Ha villagers, which are land use and income from different sources in 12 months prior to the interview. For land use information, use of production forestland for cropping were discussed. On the other hand, five main income sources which are livestock, paddy rice, swidden, cinnamon, and cardamom were focused.

Since the paper focused on contribution of forest to households which have different economic levels, the interviewed households were subjectively divided into three exclusive groups, based on their household members' income per capita, which derived from the five main income sources mentioned above. Table 1 summarizes information of these three household groups. Number of households which have annual income per capita exceeding three million VND are 11 (27\%), from one to three million are 22 (53\%), and less than one million $8(20 \%)^{1}$. They are termed in sequence as wealth groups: the High-income, Moderate-income, and Lowincome groups, accordingly.

For statistical analysis, Pearson correlation was used to determine relationship between individual variables and income per capita of household. While one-way analysis of variance (ANOVA) and Post Hoc test's Tukey honestly significant difference (HSD) were used to test the statistical significance of mean differences of each land use pattern and income source, among the three household groups.

\section{RESULTS AND DISCUSSION}

\section{Community Information}

Bang Ha village had been officially established in
1975 with seven nomad families of Dao ethnic minority. As of March 2007, the village's population pegs at 207 people living in 41 households. All are the Dao except two Tay people. Table 2 lists some demographical information and its correlation with income per capita of Bang Ha households.

A total of 152.2 hectares (ha) of production forest were allocated to 33 individual households which existed at the time of allocation (DoNRE 2006). The other eight households were five newly-formed and three newlyimmigrated households (CPC 2007). These households were shared some forestland from their parents or had to borrow from others for cultivating agricultural crops or cinnamon.

In terms of infrastructure, although having been legally formed for more than 30 years, the community is still in very poor condition. There are roads to reach to the commune centre which is about $25 \mathrm{~km}$ away, but they are mud ruts that favor a walk rather than a move of automobile or motorbike, especially in rain. Further, Bang Ha residents never have power, clean water supply, and any other public services. This also leads them to have low level of education.

\section{Livelihoods of Bang Ha Villagers}

Livelihood or income of Bang Ha villagers derives from following sources: governmental salary, petty business operation, forest product collection, animal husbandry, agricultural production, and selling of cinnamon and cardamom.

Governmental salary exists in only four people in the village. They are two village leaders, one village bodyguard, and one secretary. Similarly, only three households operate petty businesses such as rice-milling service (two households) and sundry shop running (one household). These sources of income contribute very

Table 1. Household groups based on annual income per capita (1,000 VND)

\begin{tabular}{|c|c|c|c|c|c|c|c|c|c|}
\hline $\begin{array}{c}\text { Annual } \\
\text { income per } \\
\text { capita }\end{array}$ & Group & $\mathrm{N}$ & $\%$ & Mean & $\begin{array}{l}\text { Standard } \\
\text { Deviation }\end{array}$ & Minimum & Maximum & $\begin{array}{c}\text { Total } \\
\text { income }\end{array}$ & $\%$ \\
\hline$>3$ million & High & 11 & 27 & 4,478 & 1,180 & 3,151 & 6,102 & 264,950 & 54 \\
\hline $1-3$ million & Moderate & 22 & 53 & 1,821 & 481 & 1,202 & 2,753 & 206,736 & 42 \\
\hline$<1$ million & Low & 8 & 20 & 518 & 253 & 81 & 899 & 16,953 & 4 \\
\hline Total & & 41 & 100 & 2,279 & 1,596 & 81 & 6,102 & 488,639 & 100 \\
\hline
\end{tabular}

Table 2. Demographic characteristics and their correlation with income per capita

\begin{tabular}{|c|c|c|c|c|c|}
\hline \multirow[b]{2}{*}{ Demographic characteristics } & \multirow[b]{2}{*}{ Mean } & \multirow[b]{2}{*}{$\begin{array}{l}\text { Standard } \\
\text { Deviation }\end{array}$} & \multirow[b]{2}{*}{ Sum } & \multicolumn{2}{|c|}{ Correlation with income per capita } \\
\hline & & & & Pearson $\mathrm{r}$ & $\begin{array}{l}\text { P-value } \\
\text { (2-tailed) }\end{array}$ \\
\hline Number of members (person) & 5.1 & 1.4 & 207 & .186 & .244 \\
\hline Number of labors (person) & 2.7 & 1.0 & 112 & .270 & .087 \\
\hline Labor dependent rate & 1.0 & 0.5 & - & -.087 & .588 \\
\hline Household head's age (year) & 40.4 & 13.5 & - & .196 & .220 \\
\hline Educational level of HH head (year) & 1.4 & 2.3 & - & -.016 & .919 \\
\hline
\end{tabular}

\footnotetext{
${ }^{1}$ As of October 2007, 1 Japanese Yen (JPY) approximately equals to 140 Vietnamese Dong (VND).
} 
little to the total income of the households where they exist.

Timber and non-timber forest products are other income sources Bang Ha villagers extract from forest. Forest species that have good timber quality and are usually logged by local people are cho-nau (Dipterocarpus retusus), gioi-xanh (Michelia tonkinensis), and sen-mat (Madhuca pasquieri). While non-timber forest products such as fuelwood, fodder, wild vegetables, mushroom, and wild animals are often collected or trapped.

Buffalo, cow, horse, pig, chicken, and duck are livestock raised in Bang Ha households. Of which buffalo, pig, chicken, and duck are popularly raised, while cow and horse are few.

For agricultural production, culturally Bang Ha villagers cultivate food crops in swidden fields. Their main crops are upland rice, cassava, and maize. Pumpkin, water melon, ginger, and turmeric are also sometimes cropped. In 1994, paddy rice cultivation had been introduced to the community by governmental extensionalists. Since then more and more land plots that are close to streams nearby the community's location had been reclaimed to use as paddy fields.

Cinnamon (Cinnamomum cassia) is planted in large area in production forest. It is normally monocropped, but sometimes inter-cropped with upland rice, cassava, or maize for the first one or two years. Oil extracted from cinnamon bark can be used for some industrial or medicinal purposes. Bang Ha villagers have started widely planting cinnamon since the beginning of 1990s (meaning before the forest land allocation policy), when the market demand became high. Cinnamon is actually one of the forest tree species which is ecologically suitable to plant in central and northern parts of Vietnam (DF 2007). It has also been encouraged to plant in barren forestland by silvicultural scientists. The extension of cinnamon cultivation seems to be good for improvement of forest quality in the area.

Together with extensively planting cinnamon, from the mid-1990s, some households in the community also began to plant cardamom (Elettaria cardamomum or Amomum tsao-ko) for cash income. Cardamom is a species whose seeds have high demand owing to its aromatic and medicinal properties. But since the crop requires partial shade and cool temperatures to grow (Buckingham 2004), planters in Bang Ha plant it in protection forest, where many high trees exist and temperature is always cool.

It is important to note that all cinnamon bark and cardamom seed are sold out. Timber, wild animals, and livestock are used for own consumption and sometimes sold for cash. But other non-timber forest products and all crop outputs are 100\% used for own consumption. Livestock is sold to other village members only.

Since the number of households that have had income from salary and business is small, and the study informants were unable to provide precise volume of timber and non-timber forest products they have used and sold, analyses of this paper about contribution of
Table 3. Income sources, value, and their correlation with income per capita $(1,000 \mathrm{VND})(\mathrm{N}=41)$

\begin{tabular}{lrrrc}
\hline Source & Mean & $\begin{array}{c}\text { Standard } \\
\text { Deviation }\end{array}$ & Sum & $\begin{array}{c}\text { Correlation with } \\
\text { income per capita } \\
\text { (Pearson r) }\end{array}$ \\
\hline Livestock & 674 & 778 & 27,649 & $.396^{*}$ \\
Paddy rice & 1,787 & 1,611 & 73,275 & $.478^{* *}$ \\
Cinnamon & 5,922 & 6,034 & 242,800 & $.924^{* *}$ \\
Cardamom & 468 & 1,220 & 19,200 & $.497^{* *}$ \\
Swidden & 3,066 & 1,849 & 125,715 & $.604^{* *}$ \\
\hline
\end{tabular}

* Correlation is significant at the 0.05 level (2-tailed);

** Correlation is significant at the 0.01 level (2-tailed).

income sources therefore only used data from five main sources, which are livestock, paddy rice, swidden, cinnamon, and cardamom. Table 3 shows mean and total value of each of five main income sources contributed to the households in Bang Ha village. Association of each source with income per capita or wealth of the households is also listed. It shows that cinnamon and swidden contributed largest to total income of the households, while livestock and cardamom contributed least. All five income sources have significantly positive association with income per capita. Especially, cinnamon and swidden have very strong $(\mathrm{r}=.924)$ and relative strong $(\mathrm{r}=.604)$ correlation, respectively, with income per capita.

\section{Land Use in Bang Ha Village}

Table 4 summarizes some information related to land use in Bang Ha households and illustrates their correlation with income per capita. It is important to remark that more than $80 \%$ of 152.2 ha of allocated production forest are already being used for swidden practices and cinnamon cultivation; and 9.2 ha of protection forest are being used for cardamom cultivation.

\section{Forest Land Use in Different Household Groups}

This section focuses on land use pattern of production forest among households in different wealth groups. The forest land use of the households in the community is illustrated in Figure 1 and Table 5. Generally, the better the households economically, the more production forest land they have, and vice versa. The better house-

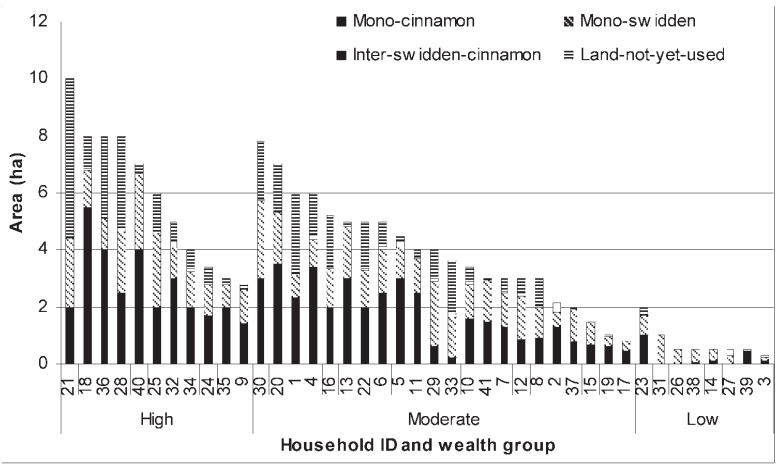

Fig. 1. Land use of production forest for cropping of households in each group. 
holds have more cropping area (cinnamon and swidden cultivation), more forestland not yet used, more land lent to others, and less land borrowed from others, than the poorer households. The High-income households do not borrowed any land from other for cropping, while $71.4 \%$ of cropping area of each household in the Low- income group is the land borrowed from others.

Specifically, on average a household in the Lowincome group has 0.3 ha of allocated forest land, while the High- and Moderate-income groups have 5.9 and 3.9 ha, respectively. Cropping area of the households in the Low-income group ( 0.7 ha on average per house-

Table 4. Land use and its correlation with income per capita ( $\mathrm{N}=41)$

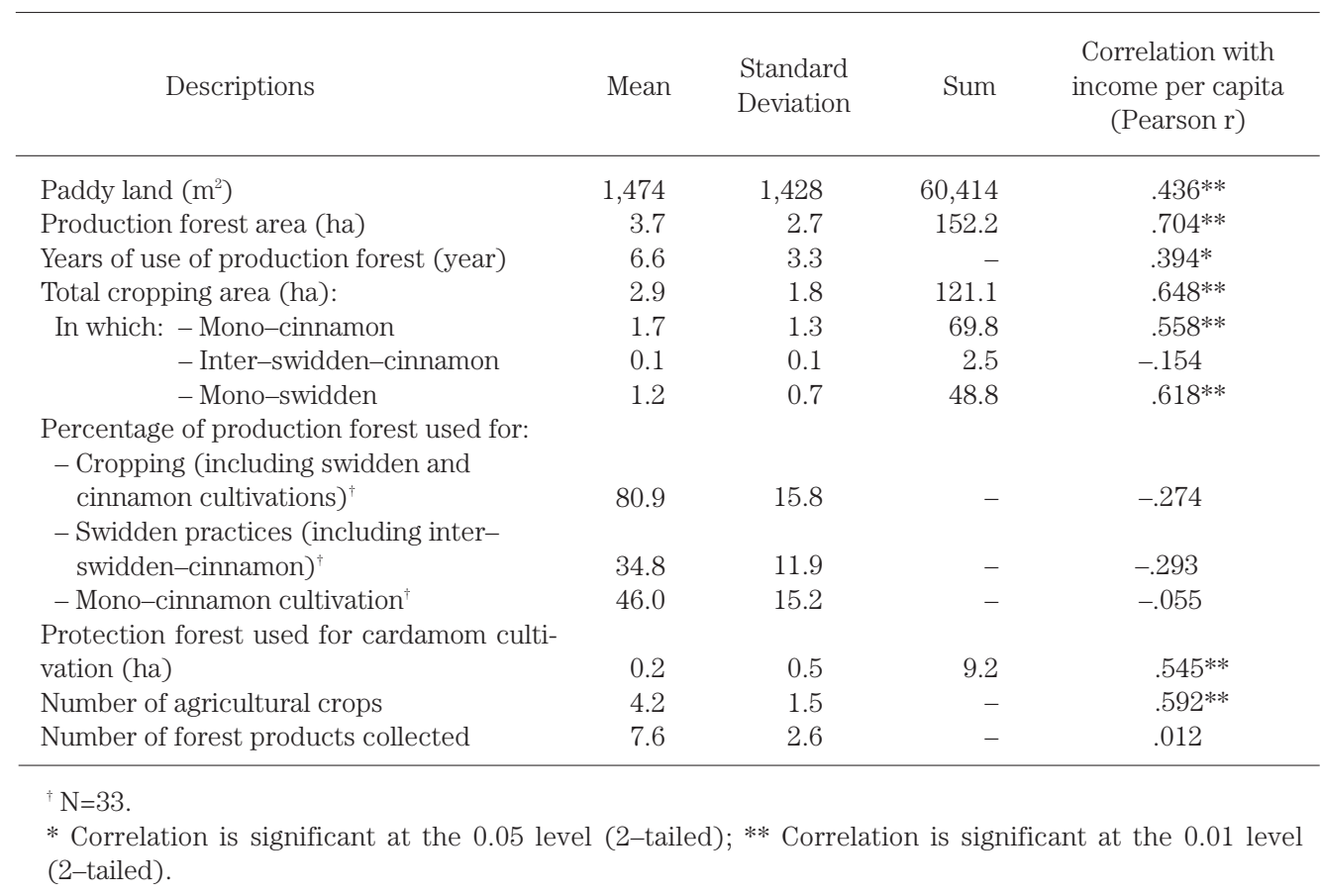

Table 5. Land use of production forest among household groups

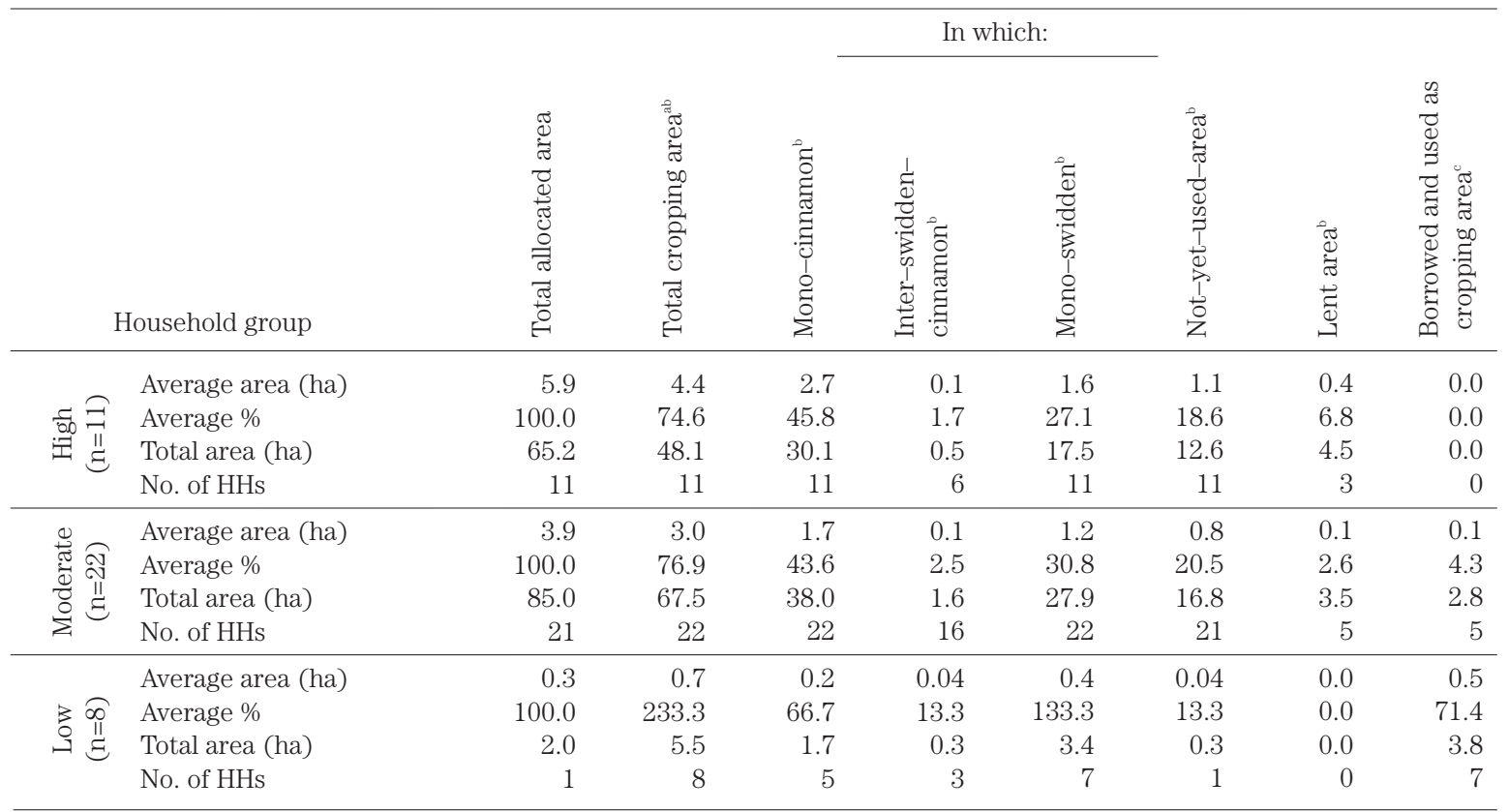

Note: Total allocated area=Total cropping area+Not yet used area+Lent area-Borrowed and used as cropping area; Total cropping area=Mono-cinnamon+Inter-swidden-cinnamon+Mono-swidden

a Total cropping area includes all fields for swiddening and areas planting cinnamon.

${ }^{\mathrm{b}}$ Percentage in total allocated production forest land.

${ }^{\mathrm{c}}$ Percentage in total cropping area being used for swidden practices and cinnamon cultivation.

ANOVA Fs of percentage of land use pattern among wealth groups: Mono-cinnamon F $(2,30)=.328$, P=.723; Interswidden-cinnamon F $(2,30)=769, \mathrm{P}=.472$; Mono-swidden $\mathrm{F}(2,30)=1.302, \mathrm{P}=.287$; Not-yet-used-area $\mathrm{F}(2,30)=.248$, $\mathrm{P}=.782$. 


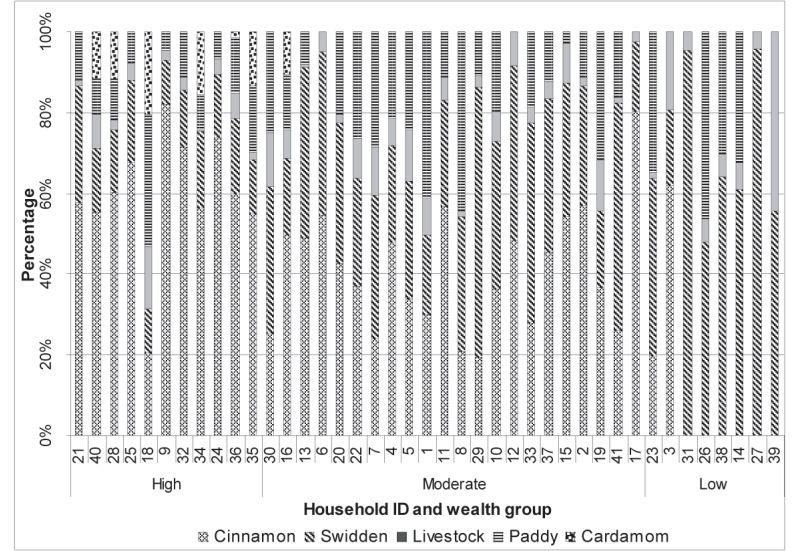

Fig. 2. Percentage contribution of five income sources in households in each group $(\mathrm{N}=41)$.

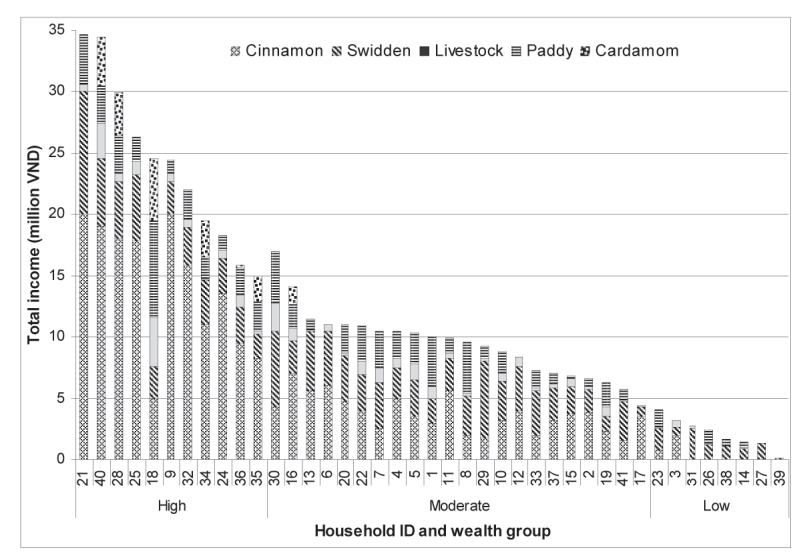

Fig. 3. Value contribution of five income sources in households in each group ( $\mathrm{N}=41)$.

Table 6. Average value, percentage, and total value of contribution of the income sources in each household group (1,000 VND)

\begin{tabular}{|c|c|c|c|c|c|c|c|c|c|}
\hline \multirow{2}{*}{\multicolumn{2}{|c|}{ Household group }} & \multicolumn{8}{|c|}{ In which: } \\
\hline & & $\begin{array}{l}\text { Cinna- } \\
\text { mon }\end{array}$ & Swidden & $\begin{array}{l}\text { Carda- } \\
\text { mom }\end{array}$ & $\begin{array}{c}\text { Forest } \\
\text { derived }\end{array}$ & $\begin{array}{l}\text { Live- } \\
\text { stock }\end{array}$ & Paddy & $\begin{array}{c}\text { Non- } \\
\text { forest } \\
\text { derived }\end{array}$ & Total \\
\hline \multirow{3}{*}{$\stackrel{\Xi 00}{0}$} & Average value & 14,345 & 4,149 & 1,609 & 20,103 & 1,126 & 2,857 & 3,983 & 24,086 \\
\hline & Average \% & $60.0^{\mathrm{ab}}$ & $16.7^{\mathrm{ab}}$ & $6.7^{\mathrm{ab}}$ & 83.4 & 4.5 & 12.1 & 16.6 & 100.0 \\
\hline & Total value & 157,800 & 45,635 & 17,700 & 221,135 & 12,390 & 31,425 & 43,815 & 264,950 \\
\hline \multirow{3}{*}{ 苞 } & Average value & 3,736 & 3,213 & 68 & 7,017 & 637 & 1,743 & 2,380 & 9,397 \\
\hline & Average \% & $41.0^{\mathrm{ac}}$ & $34.5^{\mathrm{ac}}$ & $0.5^{\mathrm{a}}$ & 76.0 & 6.4 & 17.6 & 24.0 & 100.0 \\
\hline & Total value & 82,200 & 70,680 & 1,500 & 154,380 & 14,006 & 38,350 & 52,356 & 206,736 \\
\hline \multirow{3}{*}{ 苟 } & Average value & 350 & 1,175 & 0 & 1,525 & 157 & 438 & 595 & 2,120 \\
\hline & Average \% & $10.2^{\mathrm{bc}}$ & $60.3^{\mathrm{bc}}$ & $0.0^{\mathrm{b}}$ & 70.5 & 11.5 & 18.0 & 29.5 & 100.0 \\
\hline & Total value & 2,800 & 9,400 & 0 & 12,200 & 1,253 & 3,500 & 4,753 & 16,953 \\
\hline \multirow{3}{*}{ 氶 } & Average value & 5,922 & 3,066 & 468 & 9,456 & 674 & 1,787 & 2,461 & 11,917 \\
\hline & Average \% & 40.1 & 34.7 & 2.1 & 76.9 & 6.9 & 16.2 & 23.1 & 100.0 \\
\hline & Total value & 242,800 & 125,715 & 19,200 & 387,715 & 27,649 & 73,275 & 100,924 & 488,639 \\
\hline
\end{tabular}

Note: Letters $a, b$, and $c$ attached to the numbers denote the statistical significance of mean differences of percentage among the three household groups. The mean difference is obtained from Tukey HSD Post Hoc test, after one-way ANOVA, and is significant at the .05 level.

ANOVA F tests: Cinnamon: F $(2,38)=20.540, \mathrm{P}<.000$; Swidden: $\mathrm{F}(2,38)=20.392, \mathrm{P}<.000$; Cardamom: $\mathrm{F}(2,38)=8.618$,

$\mathrm{P}=.001$; Livestock: $\mathrm{F}(2,38)=2.259, \mathrm{P}=.118$; Paddy: $\mathrm{F}(2,38)=.756, \mathrm{P}=.476$.

hold) is also smaller than that of the households in the High- and the Moderate-income groups (4.4 and 3.0 ha, respectively) (Table 5).

\section{Contribution of Income Sources in Different Groups}

This section discusses about level of contribution of the five main income sources to households in the three wealth groups. Figure 2 illustrates percentage contribution and Figure 3 exposes value contribution of the income sources. Table 6 , on the other hand, shows the average value, percentage, and total value of the source contribution among the groups, with difference tests of ANOVA F and Tukey HSD Post Hoc.

Table 6 shows that among the forest derived income sources (cinnamon, swidden, and cardamom), cinnamon contributes largest in total income of the High-income group (60.0\%) compared to the other groups (Moderateincome group: 41.0\%; Low-income group: 10.2\%). This means that cinnamon is really important for the living of local people. In contrast, swidden derived income contributes less in the High- but more in the Low-income group. In specific, swidden comprises of $16.7 \%$ in the High-, 34.5\% in the Moderate-, and 60.3\% in the Lowincome group. Cardamom derived income exists in six High-income households, only one Moderate-income household, and non among the Low-income group (Figures 2 and 3).

In general, income from the forest derived sources contributes considerably to the total annual income of all household groups: the High-income group has $83.4 \%$ of their total income derived from the forest-related sources, the Moderate $76.0 \%$, and the Low $70.5 \%$. In other words, all households in Bang Ha community have heavily lived on forest. 


\section{CONCLUSIONS}

Although the forest policy to prevent the overuse of forest land and forest resources has been applied in the community for more than half of a decade, all residents in Bang Ha Dao-ethnic community still used large proportion of forest land to cultivate their subsistence and cash-income crops. Data show that the forest area allocated to households that has been used for agricultural purposes (swidden practices) and earning cash income (cinnamon cultivation) occupies more than four-fifths of the total allocated area. Not to mention that some protection forest areas that has not been allocated to villagers, were illegally used for planting another cash crop of cardamom (Elettaria cardamomum).

Contribution of forest sources also occupies large part in income of households, regardless the households are better-off or poor. At least 70\% of a household's income was from forest. However, the richer households gained more benefits from the forest than the poorer ones.

In such communities like Bang Ha where its inhabitants have low educational level, be traditionally forestrelated, be isolated from outside world, and lack of or even do not have alternatives for livelihood, the inhabitants must depend on forest to have secured livelihood or to obtain more income. However, this dependency does not always produce negative impacts to the development of forest. Cultivation of cinnamon (Cinnamomum cassia) not only brings about considerable income for its planters, it also increases forest cover and quality. And with high economic value gaining from the planting, it is more likely that the planters will re-invest and even expand their planting area to other barren forest areas. Forest cover and quality will be more and more increased accordingly. This win-win model should be taken into account and should be expanded to other similar-conditioned places.

\section{ACKNOWLEDGMENTS}

The authors would like to thank people in the study community for their support, assistance, and provision of information during the field survey. We also appreciate the Fuji Xerox Setsutaro Kobayashi Memorial Fund and the Kyushu University Interdisciplinary Programs in
Education and Projects in Research Development for their valuable financial support for the field trip.

\section{REFERENCES}

Buckingham, S. 2004 Cardamom Cultivation in Northwest Vietnam. University of Melbourne. http://ariel.unimelb.edu. au/ johneth/Papers/SebAGREN04.htm, accessed October 19,2007

Cari, C. 2005 On the Edge of Vietnam's Forests. USLA International Institute. http://www.international.ucla.edu/ print.asp? parentid=32863, accessed November 18, 2006

CPC (Dai Son Commune's People Committee) 2007 Commune Statistics. Yen Bai

Decision 661/QD-TTg 1998 Objectives, Tasks, Policies and Implementations of the Five-million-hectare Afforestation. Prime Minister of Vietnam, Hanoi

DoNRE (Van Yen District's of Department of Natural Resources and Environment) 2006 Report on Progress of Forestland Allocation in Van Yen District. Yen Bai

FAO (Food and Agriculture Organisation of the United Nations) 2005 Global Forest Resources Assessment, 2005: Progress towards Sustainable Forest Management. FAO Forestry Paper 147. Rome

FD (Forestry Department-Ministry of Agriculture and Rural Development) 2007 Main Forest Tree Species for Production Forests in Nine Silviculturally Ecological Regions in Vietnam (in Vietnamese). http://dof.mard.gov. vn/caytrongchinh.aspx, accessed September 4, 2007

Quang, N. V. 2003 State Policies and Forest Resource Use in a Vietnamese Mountain Community. M. Sc. Thesis, Ateneo de Manila University, Manila

Sam, D. D., H. L. Son, and L. Q. Trung 2007 Forest Governance in Vietnam, In: 'Decentralisation and State-Sponsored Community Forestry in Asia.' Institute for Global Environmental Strategies (IGES), pp. 139-159

Sunderlin, W. D. and Ba, H. T. 2005 Poverty Alleviation and Forests in Vietnam. Center for International Forestry Research (CIFOR), pp. 73

VFU (Vietnam Forestry University) 2006 Forestry, Poverty Reduction and Rural Livelihoods in Vietnam. Report prepared by VFU for the Forestry Sector Support Program (FSSP), Ha Tay

Vien, T. D., N. V. Quang, and M. V. Thanh 2005 The Impacts of Decentralization of Forest Management and Livelihoods of Ethnic Minority Groups in the North-western and Northern Central Uplands of Vietnam. The Agricultural Publishing House, Hanoi, pp. 124

Yamane, M. 2003 Underlying Causes of Forest Loss in the AsiaPacific Region. In: Inoue, M. and Isozaki, H. (eds.) 'People and Forest-Policy and Local Reality in Southeast Asia, the Russian Far East and Japan.' Kluwer Academic Publishers, pp. 3-31 